\title{
Prevalence of cutaneous leishmaniasis in suspected population of District Peshawar Khyber Pakhtunkhwa Pakistan
}

\author{
Irfan Ullah ${ }^{1,}$ Muhammad Zahid ${ }^{1}$, Sahibzada Muhammad Jawad ${ }^{1,2}$, Syed \\ Salman $^{3}$, Abdul Salam ${ }^{1}$, Farman Ullah Khan ${ }^{1}$, Syeda Jawairya Hashmi ${ }^{4}$ \\ and Bilal Khan ${ }^{1}$ \\ 1. Department of Zoology, Islamia College Peshawar-Pakistan \\ 2. Department of Chemical and Life Sciences, Qurtuba University of Science and IT, Peshawar-Pakistan \\ 3. Faculty of Biological, Chemical and Environmental Science and Technology, Dalian University of Technology- \\ China \\ 4. Faculty of Life Science, Frontier Women College Peshawar-Pakistan \\ *Corresponding author's email: syedsalman@mail.dlut.edu.cn \\ Citation \\ Irfan Ullah, Muhammad Zahid, Sahibzada Muhammad Jawad, Syed Salman, Abdul Salam, Farman Ullah Khan, Syeda \\ Jawairya Hashmi and Bilal Khan. Prevalence of cutaneous leishmaniasis in suspected population of District Peshawar \\ Khyber Pakhtunkhwa Pakistan. Pure and Applied Biology. Vol. 10, Issue 4, pp1134-1140. \\ http://dx.doi.org/10.19045/bspab.2021.100119
}

\begin{tabular}{llll}
\hline \hline Received: 02/10/2020 & Revised: 18/12/2020 & Accepted: 28/12/2020 & Online First: 25/01/2021 \\
\hline
\end{tabular}

\section{Abstract}

The present study was performed for the purpose of exposing the prevalence of Cutaneous Leishmaniasis across district Peshawar. The study was fulfilled by a collection of 1023 prepared smear slides for seeking Leishmania parasite in the lesions containing population. Microscopic examination was carried out and 370 (36.17\%) cases were confirmed positive and in the remaining $653(63.83 \%)$ cases no evidence of parasite was observed. The study was analyzed through different angles of prevalence such as gender wise which concluded; male $=18.48 \%$, female $=17.69 \%$, age wise where maximum witness of parasite was observed in pre-school aged $(14.56 \%)$ and school going aged individuals (6-15\%). Whereas, month-wise statistics showed 9.38\% cases in March and $8.70 \%$ in April however, the least number of infections occurred in June $(2.93 \%)$ followed by July $(2.34 \%)$. Further molecular study is needed to analyze the genotypes of the Leishmania parasites in the studied area.

Keywords: Cutaneous Leishmaniasis; Leishmania; Peshawar; Smear formation

\section{Introduction}

Leishmania is a protozoan parasite, causes complex diseases called Leishmaniasis. After malaria and filariasis, it is the third most prevalent parasite-borne disease in the world [1]. Leishmaniasis can be presented as a model for other parasitic diseases [2]. To understand the developmental processes, mice and rats are being used for experiments [3]. Leishmaniasis can be; Cutaneous leishmaniasis (CL), Mucocutaneous leishmaniasis (MCL) and visceral Leishmaniasis (VL) [4]. It is further divided into Old World Leishmaniasis and New World Leishmaniasis. Old World leishmaniasis consists of CL which is confined to skin and VL which includes bloodstream and inner organs. But the New World Leishmaniasis includes both CL and MCL 
with the involvement of mucous membrane along with skin [5]. In Pakistan anthroponotic Cutaneous leishmaniasis is caused by Leishmania tropica whereas zoonotic Cutaneous leishmaniasis is caused by Leishmania major. Leishmania major is common in rural areas while Leishmania tropica is commonly present in urban area [6]. Leishmania parasites are transmitted by the sand fly [7]. The Phlebotomine sand-flies transmit the infection not only in tropical regions but also in subtropical and temperate regions of round about hundred countries [8]. Studies showed that nearly 15,000 cases of CL arise annually in Iran. But the actual cases are 4-5 times more than the reported [9]. Around 1,500,000 cases of Cutaneous Leishmaniasis are reported annually [10]. This parasite is mostly found in tropical region of developing countries [11]. Rodents serves as reservoir host for the parasite of Leishmaniasis, they become infected while vector feeding blood [12]. The (Table 1) shows the prevalence, main diseases, and reservoir hosts of Leishmania species [13].

Table 1. Agents of zoonotic Leishmaniases, their distribution and main reservoirs [13]

\begin{tabular}{|c|c|c|c|}
\hline $\begin{array}{l}\text { Leishmania } \\
\text { species }\end{array}$ & $\begin{array}{l}\text { Disease in } \\
\text { humans }\end{array}$ & Geographical distribution & Main reservoir host \\
\hline $\begin{array}{l}\text { Leishmania } \\
\text { (Leishmania) } \\
\text { infantum }\end{array}$ & $\begin{array}{c}\text { Visceral } \\
\text { leishmaniasis; } \\
\text { Localised } \\
\text { cutaneous } \\
\text { leishmaniasis }\end{array}$ & $\begin{array}{c}\text { Mediterranean basin; Middle East and } \\
\text { Central Asia to } \\
\text { Pakistan; China; Central and South } \\
\text { America }\end{array}$ & Dog \\
\hline $\begin{array}{l}\text { Leishmania }(\mathrm{L}) \\
\text { major }\end{array}$ & $\begin{array}{c}\text { Localised } \\
\text { cutaneous } \\
\text { leishmaniasis } \\
\end{array}$ & $\begin{array}{c}\text { North Africa, Middle East and Central } \\
\text { Asia, Sub-Saharan Africa and Sahel } \\
\text { belt }\end{array}$ & Gerbillidae rodents \\
\hline $\begin{array}{l}\text { Leishmania }(\mathrm{L}) \\
\text { aethiopica }\end{array}$ & $\begin{array}{c}\text { Localised } \\
\text { cutaneous } \\
\text { leishmaniasis; } \\
\text { Diffuse cutaneous } \\
\text { leishmaniasis } \\
\end{array}$ & Kenya & Rock hyraxes \\
\hline $\begin{array}{l}\text { Leishmania }(\mathrm{L}) \\
\text { Mexicana }\end{array}$ & $\begin{array}{c}\text { Localised } \\
\text { cutaneous } \\
\text { leishmaniasis } \\
\end{array}$ & Central America & $\begin{array}{l}\text { Various forest } \\
\text { rodents }\end{array}$ \\
\hline $\begin{array}{l}\text { Leishmania }(\mathrm{L}) \\
\text { amazonensis }\end{array}$ & $\begin{array}{l}\text { Localised } \\
\text { cutaneous } \\
\text { leishmaniasis }\end{array}$ & South America, north of the Amazon & forest rodents \\
\hline $\begin{array}{c}\text { Leishmania }(\mathrm{L}) \\
\text { venezuelensis }\end{array}$ & $\begin{array}{c}\text { Localised } \\
\text { cutaneous } \\
\text { leishmaniasis } \\
\end{array}$ & Venezuela & Unknown \\
\hline $\begin{array}{l}\text { Leishmania } \\
\text { (Viannia) } \\
\text { braziliensis }\end{array}$ & $\begin{array}{l}\text { Localised } \\
\text { cutaneous } \\
\text { leishmaniasis; } \\
\text { Mucocutaneous } \\
\text { leishmaniasis }\end{array}$ & $\begin{array}{l}\text { South America, Central America and } \\
\text { Mexico }\end{array}$ & $\begin{array}{l}\text { Numerous rain forest } \\
\text { mammals } \\
\text { (suspected) }\end{array}$ \\
\hline $\begin{array}{l}\text { Leishmania }(\mathrm{V}) \\
\text { peruviana }\end{array}$ & $\begin{array}{c}\text { Localised } \\
\text { cutaneous } \\
\text { leishmaniasis } \\
\end{array}$ & $\begin{array}{l}\text { South America, Central America and } \\
\text { Mexico }\end{array}$ & Dog \\
\hline
\end{tabular}

Visceral Leishmaniasis (VL) or Kala-azar (KA) occurs mostly in India, Nepal, Sudan,
Bangladesh, Iran and Brazil [14]. Whereas $90 \%$ of the cases of Cutaneous Leishmaniasis 
occur in Brazil, Iran, Afghanistan, Algeria, Iraq, Syria, Peru and Saudi Arabia [15]. In Europe, cases of MCL were reported in Portugal, Holland, the United Kingdom, Italy, France, Austria, Spain and Malta. Incidences of MCL were also observed in Tunisia. MCL existed in Pakistan, Iran, Saudi Arabia, SriLanka, Sudan and India, outside the Mediterranean region. Travelers regularly add in the increase of ML [5]. Principally, L. major is the cause of CL in Iran, Egypt, Pakistan, Iraq, Afghanistan, Morocco, Tunisia, Palestine, Saudi Arabia, Sudan, Syria, Yemen, Jordan and Libya [12]. In Pakistan Leishmaniasis is reported from all provinces but the endemic austerity is in hilly areas [16] Epidemiology of Leishmania is changing with the emergence of the diseases in different parts of the world. The variations in epidemic circumstances are due to the migration of population and manmade environment [17].

\section{Materials and Methods}

The current study was based on the collection of prepared slides for cutaneous Leishmaniasis. The slides and tests results were collected from different localities of district Peshawar.

\section{Study area}

The present study work was carried out in district Peshawar (Fig. 1).

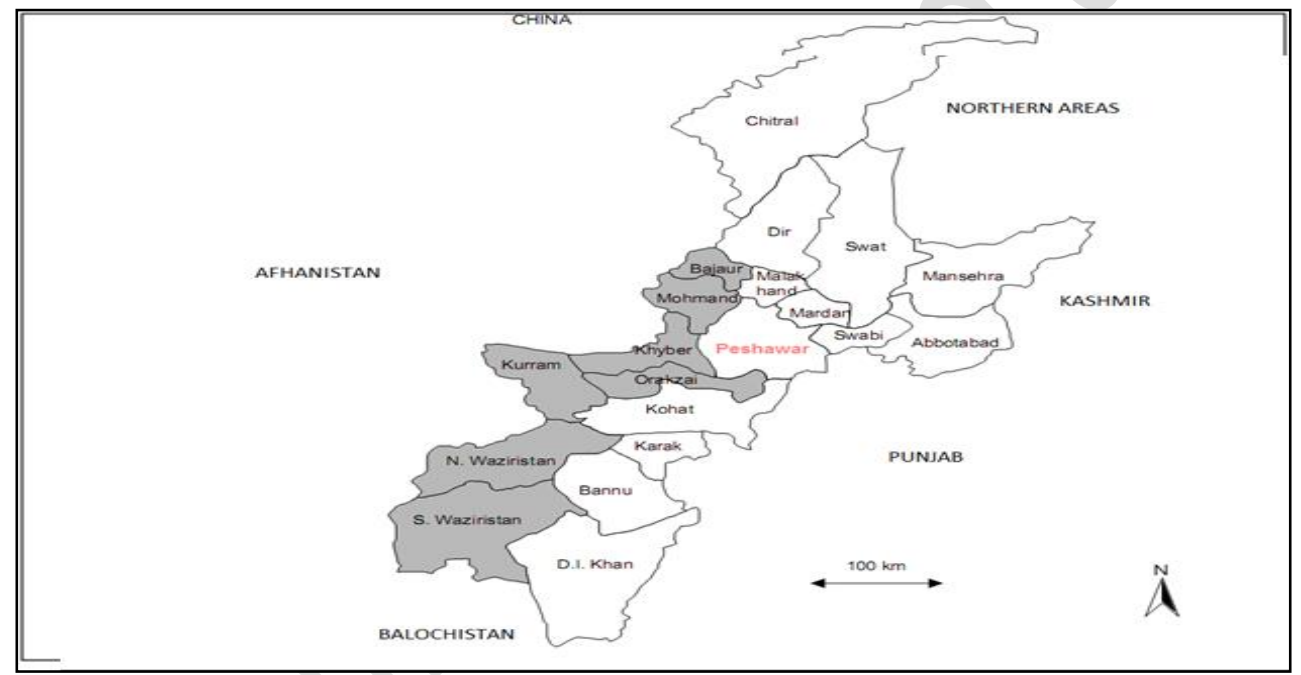

Figure 1. Map showing Peshawar district with the shaded area representing Federal administrated tribal areas

\section{Laboratory analysis}

The bite of sand fly may not be painful. At the beginning of infection, there are no symptoms but after a week the sore enlargement starts and also the number of sores (lesions) increases. After ten to fifteen days the sore appears as volcano shaped structure i.e. the raised margins of ulcer and central crater. It is then confirmed by laboratory analysis whether the lesion is leishmanoid or not.

\section{Instruments utilized}

The diagnostic methods available at present $\mathrm{f}$ or Leishmaniasis are based on clinical and ep idemiological features, parasitological detecti on (stained smears, culture and histopatholog y) and immunological methods. The result of current study was obtained by smear formation of slides. Parasites visibility was checked through the binocular microscopes (KYIWA-BIOLUX-12 and OLYMPUS-C12) with the power of $x 100$ oil immersion

\section{Results}

Overall prevalence of Cutaneous Leishmaniasis in Peshawar region

A total of 1023 slides were taken from suspected population of different regions 
located in district Peshawar. Out of the suspected population $370 \quad(36.17 \%)$ individuals were effected with cutaneous leishmaniasis (Positive) and the rest 653 (63.83\%) indicated no parasite of Leishmania (Negative). The (Fig. 2) illustrated the total incidences of Cutaneous Leishmaniasis in Peshawar.

Gender wise prevalence of cutaneous leishmaniasis in Peshawar region

The (Table 2) demonstrates that in the present study collected samples were 1023 . Out of the total suspected population $522(51.03 \%)$ were male and $501(48.97 \%)$ were female. By microscopic analysis result was as; there were $189(18.48 \%)$ males infected with Cutaneous leishmaniasis whereas 181 (17.69\%) infected females.

Age wise prevalence of cutaneous leishmaniasis in Peshawar region

The occurrence of cutaneous leishmaniasis in different age groups is given in (Table 3). The data shows that highest percentage of cutaneous leishmaniasis i.e. $14.56 \%$ was found in people of age ranged between 6-15 year of age.

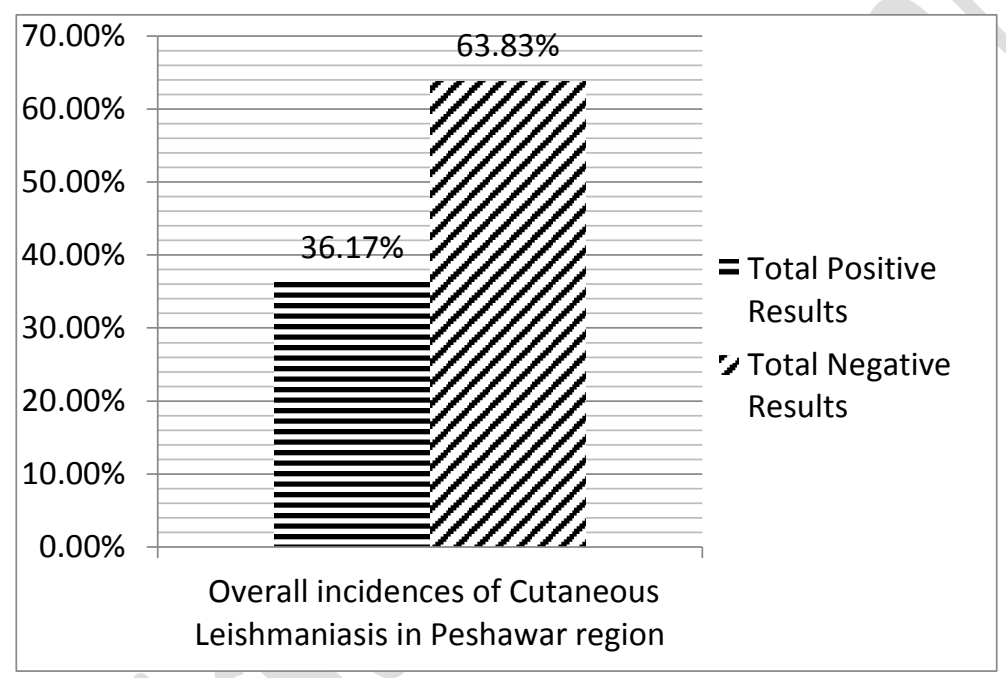

Figure 2. Overall prevalence of Cutaneous Leishmaniasis in Peshawar region

Table 2. Gender wise prevalence of Cutaneous Leishmaniasis in Peshawar

\begin{tabular}{|c|c|c|}
\hline Category & Number & Percentage (\%) \\
\hline Total samples & 1023 & 51.03 \\
\hline Total number of Male & 522 & 48.97 \\
\hline Total number of Female & 501 & 18.48 \\
\hline $\begin{array}{c}\text { Total number of Male infected with } \\
\text { Cutaneous Leishmaniasis }\end{array}$ & 189 & 17.69 \\
\hline $\begin{array}{c}\text { Total number of Female infected with } \\
\text { Cutaneous Leishmaniasis }\end{array}$ & 181 & \\
\hline
\end{tabular}

Table 3. Age wise prevalence of cutaneous leishmaniasis in Peshawar region

\begin{tabular}{|c|c|c|}
\hline Age group (Years) & Number & Percentage \\
\hline$\leq 5$ & 95 & 9.29 \\
\hline $6-15$ & 149 & 14.56 \\
\hline$\geq 16$ & 126 & 12.32 \\
\hline
\end{tabular}


Month wise prevalence of cutaneous leishmaniasis in Peshawar region

In the present study month wise prevalence of cutaneous leishmaniasis was also observed. It was detected that $40(3.91 \%)$ people were infected in January, $42(4.11 \%)$ were in
February, 96 (9.38\%) in March, 89 (8.70\%) in April. May, June and July were gradually showed lesser incidence 49 (4.79\%), 30 $(2.93 \%)$ and $24(2.35 \%)$ respectively, shown in (Fig. 3).

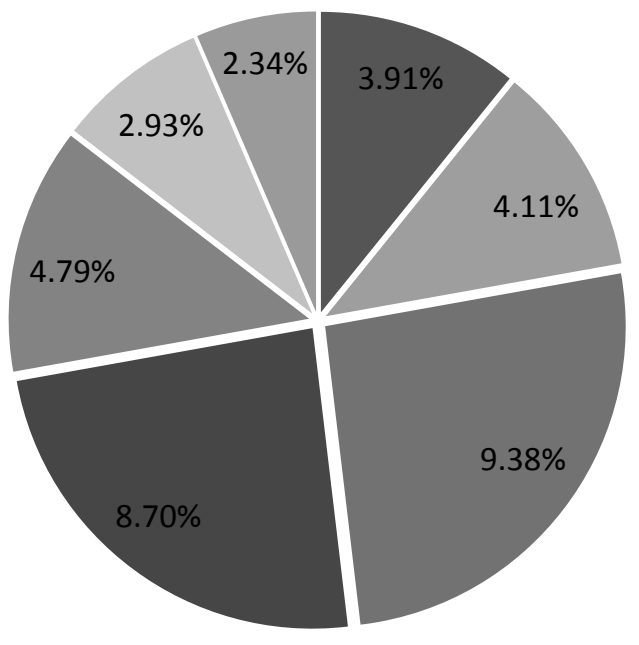

- January

February

March

April

- May

June

July

Figure 3. Month wise prevalence of cutaneous leishmaniasis in Peshawar region

\section{Discussion}

A study was conducted by Sami et al. [18] in which a total 224 patients were examined, 114 were positive, indicating $51 \%$ prevalence of leishmaniasis. The study Showed the highest prevalence $(43.8 \%)$ in $1-15$ years group and lowest $(7.0 \%)$ in $46-60$ years group. The gender wise prevalence exposed the presence of parasite $60.5 \%$ in male and $39.5 \%$ in female [18]. The recent study detailed that total of 1023 people were screened, out of 1023 cases $370(36.17 \%)$ were positive while 653 $(63.83 \%)$ were negative. The difference in the result is noticeable but the environment and climate greatly affect the prevalence of leishmaniasis. The climate of Dir favors the biological vector of leishmaniasis (sand-fly) greatly than Peshawar. That's why the distinction is shown in the current study and the study of Sami et al. [18]. The age-wise prevalence of $\mathrm{CL}$ in the present study correlated with that of the Sami et al. [18]. The study also showed maximum existence of the disease in lower aged group as the current study showed $14.56 \%$ were of age 6-15years and $9.29 \%$ were of age $\geq 5$ years. Likewise in older age the degree of infection shown decrease in both studies. Greater incidences in lower age may be due to the non-educated minds and low resistance of immune system towards the parasite. The gender wise prevalence in the current study showed a little difference as compared to previous study. The male sum was $189(18.48 \%$ ) in addition female were $181(17.69 \%)$. Present study showed negligible variation of the infection in both genders may be due to the same housing life, habitat as well as it may be the reason that the parasite of Cutaneous Leishmaniasis equally affects male and female and the infected 
female were less in number by a few, incase, the reason of culture that female are preferred to live inside houses in district Peshawar. Kakarsulemankhel [19] conducted a study in South-West of Pakistan. The prevalence of active CL in the school-aged children (11-16 years) was $45.12 \%$ cases and in children of younger age group (5-10 years) active CL was $44.11 \%$. Mostly children in the age group of 5-10 and 11-16 were infected [19]. Similar result was obtained in the recent study. The CL leishmaniasis showed precise increase in preschool aged and school-aged groups ( $\leq 5$ and 6 15 years, respectively).

An investigation was conducted by Durrani et al. [20] to determine the prevalence of Cutaneous Leishmaniasis across different regions of Pakistan. The study pointed up that cases of occurrence were most prevalent in April (518 cases) and the least number of cases during June (308 cases) and July (9\% cases) [20]. Current analysis strongly matched up with the above study. In the current study the cutaneous leishmaniasis was highly prevalent in the month of March and April while the lowest number of contaminated patients was recorded in June and July in district Peshawar.

\section{Conclusion and Recommendations}

The present study mainly prescribed that Cutaneous leishmaniasis which intensely occurred in childhood age, ranges $\leq 5-16$ years followed by older age. Overall positive cases found were $36.17 \%$ after microscopy of the slides. As the present study was not based on the species type but it was founded in a lot of studies that Leishmania tropica is the main cause of Cutaneous leishmaniasis in Peshawar moreover $L$. pepatasi is also observed in some studies. The recent study showed that the incidences of Cutaneous leishmaniasis were almost equally distributed in male and female. Recent observations demonstrated that $\mathrm{CL}$ is intensely occurring in spring season. As the month-wise record of CL showed that there were 96 infected individuals in March and likewise in April there were 89. The incidence of the disease was steadily decreased through the next months. Lowest rate of occurrence recorded in July. Studies through advanced equipment are suggested in the study area. Cutaneous leishmaniasis is one of the major health problems. It lasts for years if left untreated and cause complexity of diseases. It is mainly spread by the sand-fly. Following are some possible recommendations that can help in restriction of the occurrences of cutaneous leishmaniasis.

1. Reducing poverty and upgrading access to health care facilities in areas endemic with Cutaneous leishmaniasis.

2. Commencement of CL control campaigns in rural and backward areas to educate the residents of these areas about the prevention measurement and to make proper sewerage systems in rural areas so as to lower down breeding rates of the vector.

3. Updating laboratory equipment for advance detection of the parasite so as to cure properly.

4. Regular spraying of the rooms with Pyrethroid-containing insecticides along with the usage of bed nets soaked with Permithrin can reduce the bite of sand fly. Sand fly prefers to bite in dim light, so avoid dust and dawn outdoor activities.

\section{Authors' contributions}

Conceived and designed experiments: M Zahid \& Irfan U, Data collection and experimental work: SM Jawad, S Salman \& A Salam, Analyzed the data: Farman Ullah K, Manuscript prepared: SJ Hashmi \& S Salman.

\section{References}

1. Bhattacharya P \& Ali N (2013). Involvement and interactions of different immune cells and their cytokines in human visceral leishmaniasis. Revista da Sociedade Brasileira de Medicina Tropica 46(2):128134.

2. Todolí F, Cortés AR, Núñez MDC, Laurenti MD, Sebastián SG, Rodríguez F, Martín EP, Escribano JM \& Alberola J (2012). Head-toHead Comparison of Three Vaccination Strategies Based on DNA and Raw Insect- 
Derived Recombinant Proteins against Leishmania. Plos One 7(12).

3. Domingos PLB, Viana AG, Fraga, CADC \& Bonan PRF (2012). OX40+ T lymphocytes and IFN- $\gamma$ are associated with American tegumentary leishmaniasis pathogenesis. An Bras Dermatol 87(6): 851-855.

4. Dos-Santos MG, Muxel SM, Zampieri, RA, Pomorski TG \& Floeter-Winter LM (2013). Transbilayer Dynamics of Phospholipids in the Plasma Membrane of the Leishmania Genus. Plos One 8(1).

5. Strazzulla A, Cocuzza S, Pinzone MR, Postorino MC, Cosentino S, Serra A, Cacopardo B \& Nunnari G (2013). Mucosal Leishmaniasis: An Underestimated Presentation of a Neglected Disease. Hindawi Publishing Corporation. Biomed.

6. Afghan AK, Kassi M, Kasi PM, Ayub A, Kakar N \& Marri SM (2011). Clinical manifestations and Distribution of Cutaneous Leishmaniasis in Pakistan. Hindawi Publishing Corporation Journal of Tropical Medicine Article ID 359145, pp. 8.

7. Sansom FM, Tang L, Ralton JE, Saunders, EC, Naderer T \& Mc-Conville MJ (2013). Leishmania major Methionine Sulfoxide Reductase A Is Required for Resistance to Oxidative Stress and Efficient Replication in Macrophages. Plos One 8(2).

8. Faiman R, Abbasi I, Jaffe C, Motro Y, Nasereddin A., Schnur LF, Torem M, Pratlong F, Dedet JP \& Warburg A (2013). A Newly Emerged Cutaneous Leishmaniasis Focus in Northern Israel and Two New Reservoir Hosts of Leishmania major. Plos Negl Trop Dis 7(2).

9. Nilforoushzadeh MA, Bidabadi SL, Baghbaderani ZA, Jafari R, Beni HM, Siadat HA \& Tabrizi GM (2012). Topical effectiveness of different concentrations of nanosilver solution on Leishmania major lesions in Balb/c mice. J Vector Borne Dis 49: 249-253.

10. Sosa-Bibiano EIS, Van-Wynsberghe NR, Canto-Lara SB \& Rade-Narvaez FJ (2012). Preliminary Study towards a Novel Experimental Model to Study Localized Cutaneous Leishmaniasis Caused by
Leishmania (Leishmania) mexicana. Rev Inst Med Trop Sao Paulo 54(3):165-169.

11. Pietra RCCS, Rodrigues LF, Teixeira E, Fried L, Lefkove B, Rabello A, Arbiser J \& Ferreira LAM (2013). Triphenylmethane Derivatives Have High In Vitro and In Vivo Activity against the Main Causative Agents of Cutaneous leishmaniasis. Plos One 8(1).

12. Abdellatif MZM, Ei-Mabrouk K \& Ewis AA (2013). An Epidemiological Study of Cutaneous Leishmaniasis in Al-Jabal AlGharbi, Libya. Korean J Parasitol 51(1):7584.

13. Dawit G, Girma Z \& Simenew K (2012). A Review on Biology, Epidemiology and Public Health Significance of Leishmaniasis. Acta Parasitologica Globalis 3(3): 43-53.

14. Khanra SKS, Bandopadhyay, Chakraborty P, Datta S, Monda D, Chatterjee M, Naskar K, Roy S \& Manna M (2011). Characterization of the recent clinical isolates of Indian Kalaazar patients by RAPD-PCR method. $J$ Parasit Dis 35(2): 116-122.

15. Eslami G, Salehi R, Khosravi S \& Doudi M (2012). Genetic analysis of clinical isolates of Leishmania major from Isfahan, Iran. $J$ Vector Borne Dis 49: 168-174.

16. Khan SJ \& Muneeb M (2005). Cutaneous leishmaniasis in Pakistan. Dermatol Online $J$ 11(1): 4.

17. Kolaczinski J, Brookerb S, Reyburnb H \& Rowland M (2004). Epidemiology of anthroponotic cutaneous leishmaniasis in Afghan refugee camps in northwest Pakistan. Transactions of the Royal Soc of Tropical Med and Hyg 98: 373-378.

18. Sami Ullah Jan AH, Wazir SM \& Ali N (2009). Prevalence of cutaneous leishmaniasis in Lower Dir District (N.W.F.P), Pakistan. $J$ of Pak Assoc of Dermatol 19: 212-215.

19. Kakarsulemankhel JK (2009). "Kaal Daana" (Cutaneous Leishmaniasis) in South-West Pakistan: A Preliminary Study. Türkiye Parazitoloji Dergisix 28(1): 5-11.

20. Durrani AZ, Durrani HZ, Kamal N \& Mehmood N (2011). Prevalence of Cutaneous Leishmaniasis in Humans and Dogs in Pakistan. Pak J Zool 43(2): 263-271. 